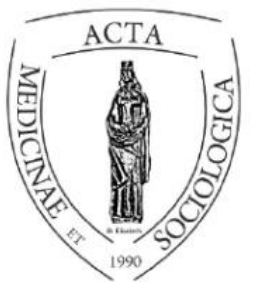

Acta Medicinae et Sociologica (2021)

Vol. 12. No. 32. (141-146)

UNIVERSITY OF

DEBRECEN

doi:

FACULTY OF

HEALTH

https://doi.org/10.19055/ams.2021.05/31/8

NYÍREGYHÁZA

\title{
Öt év múlva" - még most is aktuálisan Bernáth Krisztina: Hogyan válasszunk egyetemet? A Partiumban élő fiatalok továbbtanulási motivációi” címü könyvéről
}

Fónai Mihály ${ }^{1}$

${ }^{1}$ Debreceni Egyetem Egészségügyi Kar, egyetemi tanár fonai.mihaly@ foh.unideb.hu

Bernáth Krisztina könyve, ahogy a recenzió címe is mutatja, öt éve jelent meg. Recenzensként nem feledékenységböl írok most a müröl - az eltelt évek épp azt mutatják és igazolják, hogy a könyv elméleti elemzései és empirikus eredményei, azok magyarázatai ma is helytállóak. Néhány, a felsőoktatásban a közelmúltban lezajlott folyamat ma már csitulni látszik, az egyik a felsőoktatás expanziója, tömegesedése - a könyv ezt a folyamatot is elemzi, hisz az expanzió nagyban meghatározta a felsőoktatás európai és térségbeli folyamatait. Ebbe a folyamatba illeszthető a térség felsőoktatásának számos jelensége, így a „nem hagyományos hallgatók” (akik családjukban elsőként szereznek diplomát) magas aránya a könyvben vizsgált egyetemeken - ez a sajátossága megmaradt a térség felsőoktatásának, így ez is aktualitását adja napjainkban is a münek.

Ebből is látszik, hogy a könyv témaválasztása izgalmas, tudományos nívója alapján kiemelkedő, a vizsgált kérdésekben új tudományos eredményeket hordoz, ezek aktualitását az eltelt évek sem kérdőjelezik meg. A könyv egyedülálló a térség, a Partium felsőoktatásának az összehasonlító elemzésében. A Partium régióban müködő egyetemek közül nemcsak a magyar tannyelvűeket vizsgálja, így a nemzetközi összehasonlítás is megkerülhetetlenné teszi az írást. Fontos arról is szólni, hogy a könyv tudományosan kiemelkedő színvonalú a szakirodalom feldolgozásának és szintetizálásának, valamint a sokváltozós elemzéseken alapuló modellalkotásnak a területén is. 
A Partium, vagy magyarul „Részek”, a 16. században, a török hódoltság és török háborúk alatt olyan Erdélyhez csatlakozott, és a török által nem megszállt megyék voltak, melyek nem olvadtak teljesen össze Erdéllyel. E terület ma három országhoz tartozik, Romániához, Ukrajnához és Magyarországhoz. Számos, elsősorban felsőoktatási, de regionális és gazdasági kutatás is vizsgálja az ebben a történelmi régióban érvényesülő folyamatokat. A szerző által elemzett kutatásra 2012-ben, egy nemzetközi projekt, a HERD („Higher Education for Social Cohesion - Cooperative Research and Development in a Cross-border Arae") keretében, tíz felsőoktatási intézmény bevonásával került sor. A szerző ezek közül öt egyetem 2120 alapszakos hallgatójának a válaszait elemzi (Debreceni Egyetem, Nagyváradi Egyetem, Partiumi Keresztény Egyetem, Nagyváradi Emanuel Egyetem, Nyíregyházi Főiskola).

A szerző a könyvet nyolc fejezetre tagolta, ezek közül a Bevezetőt is beleértve négy fejezetben a téma elméleti hátterét és kutatási előzményeit vizsgálja, további négy fejezetben pedig kutatása eredményeit elemzi, illetve foglalja össze. Az elméleti és empirikus fejezetek aránya megfelelö, különösen, ha figyelembe vesszük, hogy a szerző az egyes empirikus kérdések elemzésénél a vizsgált problémákat szakirodalmi, kutatási keretekbe ágyazza, saját eredményeit folyamatosan összeveti a nemzetközi, magyar és román kutatási eredményekkel. Ez is igazolja kiemelkedő jártasságát a téma szakirodalmában, továbbá elemző, szintetizáló képességét is.

A szerző a Bevezetőben öt kérdéssel foglalkozik. A probléma felvezetésben jól foglalja össze a vizsgált föbb kutatási témákat, és azok megközelítésmódjait (szociológiai, pszichológiai, gazdasági). A kutatás célja is a továbbtanulás és szakválasztás összetett jelenségének a vizsgálata, és a potenciális gyakorlati felhasználás lehetőségeinek a körülhatárolása. A továbbtanulás, intézmény és szakválasztás mechanizmusait és az oksági összefüggéseket több nagy elméleti modell és irányzat adta értelmezési keretbe (reprodukciós, kontextuális és tőke elméletek) helyezve tárgyalja. A kutatás és a könyv a hivatkozott nemzetközi HERD kutatás keretében készült, melynek a szerző is részt vevője volt, így annak módszertanát (mérőeszközét és mintaválasztását) vette át, illetve alkalmazta.

A szerző a könyv 2., 3. és 4. fejezetében ismerteti és elemzi a teoretikus kereteket és kutatási előzményeket. A témából fakadóan a mobilitással, a felsőoktatási expanzióval, a motivációval, a továbbtanulással és a pályaválasztással összefüggő elméletek kerültek taglalásra. A szükebben vett pszichológiai motiváció elméleteken túlmenően a teoretikus értelmezések és magyarázatok, ahogy arra a szerző utal, alapvetően három nagy elméleti 
irányzat, iskola állításait fogják át, a reprodukciós elméleteket (beleértve a kulturális tőke elméleteket is), a kontextuális magyarázatokat, és a társadalmi tőke elméleteket, illetve a részben ezek által inspirált továbbtanulási elméleteket.

A könyv a továbbtanulási és intézményválasztási aspirációkat a felsőoktatás kontextusába helyezi. Ez két dolgot jelent: a felsőoktatási expanziót és az Európa 2020 Stratégiát. A stratégiát inkább csak ismerteti a szerző, ez a közpolitikák bemutatásának jellegzetes kutatói attitüdje. A felsőoktatás „fontosságát” a diplomások munkaerő-piaci lehetőségei is alátámasztják. A felsőoktatás tömegesedésről, annak okairól, időbeli folyamatairól és a magyarázatokról részletesen olvashatunk, beleértve a Partiumban lezajló felsőoktatási expanziót is. A Partium kapcsán az expanzió mellett a térség felsőoktatási intézményeinek a jellegzetességeit is taglalja a szerző - ez fontos lesz az empirikus kutatás eredményeinek az értelmezéséhez. Fontosnak tartom kiemelni, hogy a könyvben a térségben folyó felsőoktatás-és ifjúságkutatásokról is olvashatunk, e kutatások eredményeinek a bemutatása segíti a szerző empirikus vizsgálatának a jobb megértését is a vázolt kontextusok miatt.

A szerző a 3. fejezetben a továbbtanulás elméleteit foglalja össze és elemzi. Két nagy elméleti problémakört vizsgál, a motiváció elméleteket, valamint a továbbtanulás és a pályaválasztás elméleteit. A motiváció elméletek közül a legfontosabbakat elemzi, azokat a továbbtanulást, a választást és a döntést magyarázó elméletekként értelmezi. A 3.2. fejezet, mely a továbbtanulásra és a pályaválasztásra fókuszál, a 2.1. fejezetben vázolt főbb irányzatok és magyarázatok részletesebb kifejtését adja, segítve ezzel a továbbtanulási döntések jobb megértését. Az egyenlőtlenségek lehetséges magyarázatai mellett, pontosabban azokkal összefüggésben, az iskolai eredményesség és a továbbtanulás lényeges elméleteit is vázolja a könyv, benne a reprodukciós és a kontextuális magyarázatokat. A továbbtanulás meghatározó kérdése a választás és a hozzáférés esélye - ennek a szociológiai, gazdasági és pszichológiai megközelítésmódjait és teoretikusait színvonalasan mutatja be a mü.

A könyv 4. fejezete a kutatási előzményeket fogja át. A szerző négy kérdésre koncentrál, a továbbtanulási motívumokra, a társadalmi háttérre, a kapcsolati tőkére, a szakválasztás folyamatára, és a nemi különbségekre. A szakválasztást a felsőoktatási továbbtanulási és az intézményválasztási döntésekre ható tényezők kontextusában is elemzi a szerző, így a három választás (továbbtanulás, intézmény, szak) egy átfogó döntési folyamatot 
jelent, melynek lépcsői, elemei egymással szoros kapcsolatot feltételeznek. E döntések, választások közül kevésbé ismert a szakválasztásnak a tudományterületekkel, a családi háttérrel és a nemekkel összefüggő mechanizmusa. A szakirodalom elemzése alapján a szerző lényeges különbségeket mutat be például a humán, a természet, a müszaki, az orvos és a társadalomtudományok végzősei között (mivel végzős hallgatókról van, szó, az egyetemi tanulmányok előtti szakválasztás megragadható különbségeiről lehet beszélni, például a nemek között, a várt jövedelemre vonatkozóan, vagy az anyák és az apák szerepét, befolyását illetően). A vonatkozó kutatási eredményeket, nemcsak mint a döntésekre ható tényezőket ismerteti, azokat értelmezi is, így ez a fejezet túlmegy a kutatási előzmények puszta „leltárján”, sokkal inkább egyfajta „középelmélet” a témát érintő elméletek és a saját empirikus kutatása között.

A HERD empirikus kutatásának részét képező eredményeket az 5 . fejezet foglalja össze, három alfejezetre tagolva. Az 5.1. alfejezet a kutatás céljait, főbb kérdéseit, a módszereket, a mintaválasztást és a hipotéziseket ismerteti. A magas tudományos színvonalat képviselő fejezetből is ki kell emelni a kutatási kérdések, a hipotézisek és a statisztikai elemzések alfejezeteit. Hipotéziseit a szakirodalomból vezeti le, azok a hipotézisekkel szemben megfogalmazott, tartalmi és formai kritériumoknak megfelelnek, és jól tesztelhetők. A hipotézisek a társadalmi státusz és az intézmény presztízse, valamint a nemek és a szakmai sztereotípiák összefüggéseire vonatkoznak. A könyv egyik, meghatározó új tudományos eredménye a sokváltozós elemzésekre „épített” magyarázó modellek kialakítása - erre az empirikus elemzés további részeiben kerül sor, ami módszertanilag kiemelendő, az az, hogy a szerző az alapmegoszlások és kereszttáblák eredményei alapján, és korábbi elméleti várakozásainak megfelelően dolgozza ki a magyarázó modelleket és az azokat igazoló sokváltozós elemzéseket - ez nagyfokú módszertani felkészültséget igényel.

A kutatási eredmények bemutatására két alfejezetben kerül sor. Az 5.2. címe a „Kutatási eredmények bemutatása”, míg az 5.3. fejezeté „A felsőoktatási rendszerbe lépők továbbtanulási motivációi”. Az 5.2. fejezet a vizsgált minta szocio-demográfiai elemzéséről szól, azaz nem az összes, főbb empirikus kutatási eredmény ismertetéséről. Maga az elemzés színvonalas, a szerző az egyes kérdések taglalásánál bemutatja a vonatkozó szakirodalmi és kutatási eredményeket, azokat összeveti a saját tapasztalataival. Ez az eljárás akár kétélü is lehetne, hisz erősítheti, de redundánssá is teheti a szöveget ebben az esetben az elméletekkel való összevetés a könyv előnyére vált. 
A hallgatók szocio-demográfiai hátterét igen gazdagon mutatja be a szerző, sor kerül a nemek, az életkor, a településtípus és a középiskolák szerinti megoszlások elemzésére. Ezen túlmenően a válaszadók társadalmi hátterét, a szülők iskolai végzettségét, gazdasági aktivitását, foglalkozását, a családok anyagi helyzetét és jóléti mutatóit is vizsgálja. Az eredmények azt mutatják, hogy a mintába került hallgatók vidéki vagy kisvárosi származásúak, és a szülők jellegzetesen középfokú végzettségüek, más megközelítésben magas a „nem hagyományos” (első generációs értelmiségi) hallgatók aránya, hisz az apáknak csak egynegyede, az anyáknak egyharmada felsőfokú végzettségü.

$\mathrm{Az}$ 5.3. fejezetben a továbbtanulási motivációk nagyon alapos, mély elemzésére kerül sor, a szerző faktorelemzésekkel keresi a látens változókat a továbbtanulás, az intézmény és a szakválasztás kapcsán. Elemzései helytállóak és izgalmasak, ezeket is folyamatosan összeveti a szakirodalmi elözményekkel és modellekkel. Az 5.4. fejezetben újabb „szintet lép” a könyv, a szerző a már feltárt jelenségek és összefüggések modell magyarázatait dolgozza ki, értően és indokoltan alkalmazva a sokváltozós elemzéseket. Kritikai észrevételem is ehhez kapcsolódik: az olvasók jelentős része nem tájékozott ezekben a módszertani, statisztikai kérdésekben, ilyenkor tanácsos volna utalni az sokváltozós eredmények értelmezésére (a szerző mentségére szóljon, hogy a sokváltozós elemzésekkel operáló írások túlnyomó többsége nem tér ki az eredmények értelmezésének a kérdésére). Ugyanakkor a szerző a következtetések levonásakor a „laikus” olvasó számára is érthetően mutatja be az eredményeket.

A 6-8. fejezetekben összegzésre és kitekintésre vállalkozik a mü. A könyv összefoglalása színvonalas, izgalmas, nem redundáns, valóban új kérdéseket vet fel, itt mutatja be azokat az eredményeket, melyek új tudományos eredményként értelmezhetők (pl. az alacsony státuszú hallgatók intézmény és szakválasztásának sajátosságait egy relatíve fejletlen régióban).

A könyv struktúrája és formai kivitelezése áttekinthető, esztétikus, érthető. A szerző szakirodalmi jártasságát jelzi, hogy 286 irodalmat dolgozott fel, ezek angol, román és magyar nyelvüek, jelentős részükre hivatkozik is. A szakirodalmi háttér korábbi doktori iskolájának (Debreceni Egyetem BTK Humán Tudományok Doktori Iskolája), a CHERD Kutatóközpontnak és a HERD kutatásoknak az eredményeit is magába foglalja, a szerző érzékelhetően e tudományos mühelyekhez tartozónak (is) tartja magát.

Bernáth Krisztina könyvét fontos oktatás, felsőoktatás-szociológiai írásnak tartom, mely számos új tudományos eredményt foglal magába. Képes az elméleti kérdések szintetizálására, és az empirikus eredmények alapján új 
modellek megalkotására. Eredményei hozzájárulnak a térségben (a Partiumban) müködő regionális egyetemek hallgatói rekrutációjának és a hallgatók továbbtanulási, intézmény-és szakválasztási döntéseinek a jobb megértéséhez. Ez, ahogy maga a szerző is megfogalmazza, hatással lehet az intézmények rekrutációs gyakorlatára, a felsőoktatás-politikákra és az oktatásszociológiai kutatásokra is. Ezek alapján a könyvet igen széles körnek ajánlhatom, a döntéshozóktól a laikus érdeklődőkig.

Bernáth Krisztina (2016): Hogyan válasszunk egyetemet? A Partiumban élő fiatalok továbbtanulási motivációi. Cluj-Napoca, Presa Universitară Clujeană 